\title{
Equine pythiosis: Report of 28 cases from São Paulo State, Brazil
}

\author{
Pitiose em equinos: Relato de 28 casos no estado de São Paulo, \\ Brasil
}

\author{
Marcos Jun Watanabe ${ }^{1}$; Juliana de Moura Alonso ${ }^{2}$; Ana Liz Garcia Alves ${ }^{1}$; \\ Ana Lúcia Miluzzi Yamada²; Sandra de Moraes Gimenes Bosco ${ }^{3}$; \\ Celso Antônio Rodrigues ${ }^{1}$; Carlos Alberto Hussni ${ }^{*}$
}

\begin{abstract}
Pythiosis is a granulomatous lesion of the skin and subcutaneous tissues caused by Pythium insidiosum, a microorganism belonging to the Stramenopila Kingdom and the Oomycetes Class. The pathogen is commonly found in water environments, mainly in tropical areas of the world. Twenty eight cases of equine pythiosis were presented at the Large Animal Surgery Department of the School of Veterinary Medicine and Animal Science, São Paulo State University, Brazil in six years. Among the 28 animals, 13 presented distal lesions on the limbs, with four being immediately euthanized and seven dying due to loss of body condition leading to cachexia. The horses presented with one or more wounds in the body, distributed as follows: limbs (13 distal, four proximal), abdominal region (7), thoracic region (1), pectoral region (1), lumbar region (1), nasal region (1) and prepuce (1). The diagnosis was made by the association of the macroscopic aspects of the lesions with the histopathology, isolation of the pathogen and/or nested-PCR. Treatments included surgical removal of the lesion (16), potassium iodide $67 \mathrm{mg} \mathrm{kg}^{-1}$ PO sid (23), intravenous regional perfusion with $50 \mathrm{mg}$ of amphotericin B (6) and immunotherapy (8). Pythiosis is a disease that develops quickly, but its diagnosis is time-consuming; therefore, establishing an early treatment with special attention to the involvement of distal regions of the limbs is important. Key words: Equine, granulomatous, pythiosis, Pythium insidiosum, surgery, wound
\end{abstract}

\section{Resumo}

A pitiose é uma doença granulomatosa do tecido cutâneo e subcutâneo causado pelo oomiceto Pythium insidiosum, microorganismo pertencente ao reino Stramenopila, classe Oomycetes. O agente é comumente encontrado em ambientes aquáticos, principalmente nas áreas tropicais do mundo. Foram atendidos 28 casos no Serviço de Clínica Cirúrgica de Grandes Animais da Faculdade de Medicina Veterinária e Zootecnia, UNESP, Botucatu, São Paulo, Brasil. Dentre os 28 animais, 13 apresentaram lesões distais de membro, sendo quatro imediatamente submetidos à eutanásia e sete morreram devido à perda progressiva de condição corporal levando a caquexia. Os equinos apresentaram uma ou mais lesões, distribuídas da seguinte forma: membros (13 distais e quatro proximais), região abdominal (7), região torácica (1), região peitoral (1), região lombar (1), região nasal (1), prepúcio (1). O diagnóstico foi baseado na associação dos achados macroscópicos, histopatológicos, isolamento do patógeno e/ou nested-PCR. Os tratamentos incluíram: remoção cirúrgica (16), iodeto de potássio $67 \mathrm{mg} \mathrm{kg}^{-1} \mathrm{VO}$ Sid (23), perfusão regional com $50 \mathrm{mg}$ de anfotericina B (6) e imunoterapia (8). A pitiose é uma doença

\footnotetext{
${ }^{1}$ Profs., Faculdade de Medicina Veterinária e Zootecnia, FMVZ, Botucatu, SP, Brasil. E-mail: watanabe@fmvz.unesp.br; anaalves@fmvz.unesp.br; rodriguesca@fmvz.unesp.br; cahussni@fmvz.unesp.br

2 Discentes, FMVZ, Botucatu, SP, Brasil. E-mail: juliana.alonso@fmvz.unesp.br; anayamada@fmvz.unesp.br

3 Prof ${ }^{a}$, Instituto de Biociências de Botucatu, IBB, Botucatu, SP, Brasil. E-mail: smgbosco@ibb.unesp.br

* Author for correspondence
} 
de rápido desenvolvimento, sendo imprescindível o diagnóstico rápido com especial atenção às lesões localizadas na região distal do membro.

Palavras-chave: Cirurgia, equinos, feridas, granuloma, Pythium insidiosum, pitiose

\section{Introduction}

Pythiosis is a potentially life-threatening disease of mammals and man, characterized by granulomatous, exudative and itchy lesions of cutaneous and subcutaneous tissues. It is caused by the organism called Pythium insidiosum, an oomycete belonging to the Kingdom Stremenopila, Phylum Oomycota, Class Oomycetes, Family Pythiaceae. The disease occurs predominantly in tropical and subtropical areas and has been reported mainly in the Americas and Southeastern Asia (GAASTRA et al., 2010; SALLIS et al., 2003).

The genus Pythium comprises phytopathogenic species, and the most common species to cause disease in animals is $P$. insidiosum, although $P$. aphanidermatum, a species that occasionally causes disease in humans, has been identified recently (CALVANO et al., 2011). The organism lives in aquatic environments with the presence of vegetation, and thus pythiosis is also known as "swamp cancer" (AUSTWICK; COPLAND, 1974).

In Brazil, the disease occurs predominantly in horses and dogs, and outbreaks of pythiosis have been reported in sheep and in cattle (CARRERA et al., 2013; GABRIEL et al., 2008; TORRES NETO et al., 2010; SANTOS et al., 2011a). There has been only one case reported of human pythiosis in Brazil. The patient acquired the disease in a lake whilst fishing in standing water (BOSCO et al., 2005; MARQUES et al., 2006). The disease also occurs in cats, but it has not yet been reported in Brazil (GAASTRA et al., 2010).

Due to its affinity with water environments and vegetation, the life cycle of this organism comprises the formation of sporangium at the tip of hyphae that grows on grasses. Inside the sporangium, the protoplasmatic material flowing from the hyphae is cleaved and matures to form zoospores. Once maturated, these biflagelated zoospores are released into the water and swim around for 10-15 minutes until encystation in plant material or damaged mammalian skin. Once they penetrate the skin, the zoospores lose their flagella, and a germinative tube develops to initiate hyphae growth, which is the invasive form of the pathogen. The optimal temperature for its growth is approximately 30$40{ }^{\circ} \mathrm{C}$, similar to mammalian body temperatures (KRAJAEJUN et al., 2010).

The macroscopic characteristics of the lesion in horses are the exuberant granulomatous tissue, which develops within few weeks, and drainage of serosanguineous to pyogenic exudates. The marked characteristic of equine pythiosis is the formation of "kunkers", which correspond to small granulomas containing hyphae surrounded by eosinophils (KRAJAEJUN et al., 2010). Pruritis is intense and leads to self-mutilation of the lesion in an attempt to relieve the discomfort (GAASTRA et al., 2010). Treatment of equine pythiosis consists of surgical removal, administration of antifungal drugs, such as amphotericin B and iodide compounds, and immunotherapy (DÓRIA et al., 2012; GAASTRA et al., 2010).

\section{Cases presentation}

A total of 28 horses (11 geldings and 17 mares), aged 3-21 years old and of different breeds, were attended at the Hospital of the School of Veterinary Medicine and Animal Science at UNESP/Botucatu, Brazil, between 2007-2012. These horses came from different regions of São Paulo State, and had free access to natural reservoirs of water or swamp areas with high environmental temperatures. 


\section{Clinical findings}

The lesions presented in different locations and sizes, with 17 presenting wounds on their limbs (four in the proximal limb and 13 in the distal limb), seven on their abdomen, and the remainder with single lesions over the chest, esternum, lumbar, nostril and prepuce regions (Table 1). One of the horses presented two lesions (abdominal and proximal limb). All patients presented with intense pruritis and the wounds have been rubbed against objects or self-mutilated by bites; thus, blood and secretions around the lips and bleeding wounds were commonly observed. The granulomatous lesions presented with ulceration and irregular aspects, containing exudates ranging from serosanguineous to mucopurulent. Fistulous tracts, focal necrosis and characteristic foul odors were also observed, in addition to the presence of yellowish masses ("kunkers").

Table 1. Distribution of cases, gender, lesion location, treatment and outcome of horses affected by pythiosis.

\begin{tabular}{ccccc}
\hline Case & Gender & Site of lesion & Treatment & Outcome \\
\hline 1 & $\mathrm{M}$ & Spine & $\mathrm{KI}^{\mathrm{b}}$ & Remission \\
2 & $\mathrm{G}$ & Chest & KI/ Immunotherapy & Remission \\
3 & $\mathrm{G}$ & Prepuce & Surgery/KI & Death \\
4 & $\mathrm{G}$ & Nostril & Surgery/KI & Remission \\
5 & $\mathrm{M}$ & Sternum & Surgery/KI/Immunotherapy & Remission \\
6 & $\mathrm{M}$ & Abdomen & KI & Remission \\
7 & $\mathrm{M}$ & Abdomen & Surgery/KI & Remission \\
8 & $\mathrm{G}$ & Abdomen & Immunotherapy & Remission \\
9 & $\mathrm{M}$ & Abdomen & KI & Remission \\
10 & $\mathrm{G}$ & Abdomen & Surgery/KI & Remission \\
11 & $\mathrm{M}$ & Abdomen and olecranon & Surgery/KI & Remission \\
12 & $\mathrm{M}$ & Abdomen & KI & Remission \\
13 & $\mathrm{M}$ & Semitendinosus muscle & Surgery/KI/Immunotherapy & Remission \\
14 & $\mathrm{G}$ & Semitendinosus muscle & Surgery/KI & Remission \\
15 & $\mathrm{G}$ & Semimembranosus muscle & Surgery/KI & Remission \\
16 & $\mathrm{M}$ & Metacarpophalangeal joint & KI/Immunotherapy & Remission \\
17 & $\mathrm{M}$ & Carpus & KI/ Amphotericin B/Immunotherapy & Death \\
18 & $\mathrm{G}$ & Metacarpophalangeal joint & Surgery/KI & Death \\
19 & $\mathrm{M}$ & Metacarpophalangeal joint & None & Euthanasia \\
20 & $\mathrm{M}$ & Metacarpophalangeal joint & Surgery/KI/Amphotericin B/Immunotherapy & Death \\
21 & $\mathrm{G}$ & Metacarpophalangeal joint & Surgery/KI/Amphotericin B & Death \\
22 & $\mathrm{M}$ & Metacarpophalangeal joint & Surgery/KI/Amphotericin B & Remission \\
23 & $\mathrm{M}$ & Metacarpophalangeal joint & Surgery/KI/Amphotericin B & Death \\
24 & $\mathrm{G}$ & Metacarpophalangeal joint & None & Euthanasia \\
25 & $\mathrm{M}$ & Metacarpal & Kurgery/KI/Amphotericin B & Death \\
26 & $\mathrm{M}$ & Metacarpophalangeal joint & None & Death \\
27 & $\mathrm{M}$ & Metacarpophalangeal joint & None & Euthanasia \\
28 & $\mathrm{G}$ & Metacarpal & Euthanasia \\
\hline
\end{tabular}

${ }^{\mathrm{a}}$ Gelding (G) and Mare (M). ${ }^{\mathrm{b}}$ Potassium iodide (KI).

Potassium iodide dose $=67 \mathrm{mg} \mathrm{kg}^{-1}$ VO SID; Amphotericin B dose $=50 \mathrm{mg} /$ animal. 
Horses that showed wounds on their limbs presented with varying degrees of lameness due to the structures compromised by the lesion. Animals that exhibited intense lameness and deep wounds presented periosteal proliferations, which were observed by radiographic and post mortem examinations.

\section{Diagnosis}

This was based on the gross lesions, histopathology and identification of the pathogen or nested-PCR with specific primers, as proposed by Grooters and Gee (2002). Concerning the macroscopic aspects, the granulomatous and ulcerative pattern, observation of pruritis, presence of serosanguineous to mucopurulent exudates and presence of fistulous tracts with kunkers were considered.

The histopathology revealed suppurative and granulomatous inflammation characterized by hyphae surrounded with degranulated eosinophils and collagen. The hyphae margins contained intact eosinophils and neutrophils, which composed an inflammatory exudate.

The culturing of $P$. insidiosum was performed with several washes of freshly removed kunkers from the lesions with saline and chloramphenicol $\left(50 \mu \mathrm{g} \mathrm{mL}^{-1}\right)$. The kunkers were sliced and plated on Sabouraud Dextrose Agar (SAB) $4 \%$ and incubated at $35{ }^{\circ} \mathrm{C}$ for 24 hours, which was enough time to observe the hyphal growth of the pathogen. When culturing was not possible, DNA extraction from the kunkers was performed, and nested-PCR was employed to confirm the molecular identity of the pathogen.

\section{Treatment}

The principal treatment was surgery to completely or partially remove the lesion combined with potassium iodide (Vetec $\AA$ - Sigma Aldrich Co)
(67 mg kg-1, SID) for 45 - 60 days. This protocol was used in 16 cases, and some of them required repeated surgical approach (Table 1). Among the cases presented, all horses with lesions not located in the distal limb achieved total remission of the lesions, with exception of the horse which lesion was in the prepuce that died because a colic episode not related with pythiosis. However, of 13 horses with lesions in the distal region of the limbs, only two were cured. These animals presented recent lesions and one of them was also submitted to amphotericin B treatment. Potassium iodide not associated with surgery was used in 8 cases where surgical debridement was not possible or necessary. The horses that showed lesions in the distal regions of their limbs and had no improvement with potassium iodide were submitted to treatment with amphotericin B and/or immunotherapy. Amphotericin B (Funtex ${ }^{\circledR}$ - Meizler Biopharma S/A, São Paulo, Brazil ), 50 mg/animal, was administered by intravenous regional perfusion after a tourniquet was applied above the lesion. After 40 minutes, the circulation was slowly released. This approach was employed in six animals and repeated after 14 days if necessary, according to the progression of the lesion (Table 1).

Immunotherapy with Pithium Vac ${ }^{\circledR}$ (Lapemi/ Embrapa, Santa Maria, Rio Grande do Sul, Brazil) was performed in seven animals by the subcutaneous route in the neck region every 14 days, according to the manufacturer's instructions. In the majority of cases, three to five applications were necessary (Table 1). An efficacy of $71.4 \%$ was observed among the horses treated with immunotherapy. Only one animal was treated exclusively with immunotherapy, with the remaining treated in conjunction with surgery and/or potassium iodide (Table 1).

The treatment choice was based on the assessment of the possibility of surgical excision and on lesion extension. The standard treatment was the association of surgical excision and potassium iodide. In the absence of excision 
possibility and/or responsiveness to therapy, other therapeutic possibilities were added. The addition of immunotherapy was enlightened to the owner, and added or not to the treatment depending on the extent of injury and the owner financial condition.

\section{Outcomes}

Among the 28 animals evaluated, those considered cured were those with lesions found in proximal regions of their limbs and abdominal, nasal, chest, lumbar and esternum regions. Among the 13 animals that presented lesions in the distal regions of their limbs, four were euthanized immediately, seven died due to the progressive loss of their body condition leading to cachexia, and only two were cured (Table 1). The animal with a lesion in the prepuce died during the treatment due to colic not related to pythiosis.

Euthanasia decision was based on the extent and depth of injury associated with prolonged evolution, lameness, weakness and cachexia.

\section{Post mortem findings}

The post mortem descriptions by the pathologists corroborate the macroscopic findings of the lesions. Systemic involvement was not observed. In two of the euthanized animals, which had a disease duration greater than 90 days, the penetration of the pathogen into the bone tissue with resulting periosteal proliferation was observed.

\section{Discussion}

The 28 cases herein reported occurred during the last seven years, with 23 occurring in the last three years. This incidence demonstrates the great importance of this disease, which has become emergent. We observed that these cases occurred after rainy periods, especially in swampy areas with great hydric effluents, which has been previously demonstrated in the literature (LEAL et al., 2001).
The macroscopic aspects of the wounds were in accordance with the previous literature, which has reported a high occurrence of unique lesions, although multifocal lesions have been described (GAASTRA et al., 2010; LEAL et al., 2001; MOSBAH et al., 2012). The lesions on the limbs are common (SALLIS et al., 2003) and evolved quickly with great exudation due to the amplitude of the wounds and constant loss of the body condition, with anemia and hypoproteinemia as consequences of intense blood discharge observed in the lesions. The evaluated animals that presented extensive wounds on their limbs that reached deep structures showed lameness of several degrees, especially if the lesions affected the periosteal regions. No systemic disease was observed among the animals that died or had to be euthanized, corroborating the literature that highlights the high incidence of cutaneous lesions in equine pythiosis (GAASTRA et al., 2010; LEAL et al., 2001; MOSBAH et al., 2012).

Pythiosis is diagnosed by the association of the macroscopic aspects of the lesion, histopathology, cytology, immunohistochemistry, serology, culture and, recently, molecular approaches. Histopathology and cytology do not differentiate between the hyphae from $P$. insidiosum and zygomycetes fungi (GAASTRA et al., 2010, SANTURIO et al., 2006b). Its early diagnosis is difficult as several differential diagnoses can be considered, such as cutaneous habronemosis, neoplasia, exuberant granulomatous tissue and fungal and bacterial granulomas (GAASTRA et al., 2010; LEAL et al., 2001; WHITE, 2005).

Treatment is difficult because an early definitive diagnosis is seldom made. The pathogen does not respond satisfactorily to antifungal compounds, although they are widely employed in its treatment. $P$. insidiosum lacks ergosterol in its cellular membrane, the main target of azoles, allylamines and polyenes. The treatment of choice is surgical removal of the entire lesion, which is not always feasible due to the unclear anatomic localization 
of the lesions, especially in the limbs (LEAL et al., 2001; SANTURIO et al., 2006a). The combined administration of antifungal compounds, iodide (such as potassium and sodium iodide) and immunotherapy is common (GAASTRA et al., 2010; SANTURIO et al., 2006a).

According to Chaffin et al. (1992), the combination of potassium iodide with surgery allowed better results for the treatment of equine pythiosis. In the present report, some animals with lesions in the distal parts of the limbs did not respond well to the combination of surgery and potassium iodide, leading to other therapies, such as amphotericin B and immunotherapy.

Amphotericin B is an antimycotic agent from the polyene group with an efficacy reported to be 92 $\%$ in conjunction with surgery and thermocautery (DÓRIA et al., 2012). In the present study, only one animal had total remission of the lesion with such an approach.

The immunotherapy success rates varied from 50-83.3 \% (MENDOZA et al., 1986, 1992; SANTOS et al., 2011b) and when in association with surgery these rates increases to $90 \%$ (SANTOS et al., 2011b). In the present study, a similar rate described by Santos et al. (2011b) was observed (71.4\%), however this rate was achieved with immunotherapy alone and/or associated with surgery and/or potassium iodide.

It is important to emphasize that the most effective treatments were surgical removal of the lesion combined with potassium iodide and immunotherapy. However, independent of the treatment adopted, when lesions were found in the distal part of the limbs, the prognosis was unfavorable as 11 out of 13 animals with lesions in the distal part of the limbs died.

The low rate of remission presented in distal limb rests on the fact that the equine species has peculiarities such as chronic inflammation, exuberant development of granulation, slow epithelialization and inefficient contraction
(THEORET; WILMINK, 2008). The healing difficulty in distal limb can also be attributed to anatomical and physiological characteristics of this region, which includes smaller blood supply, joint high mobility, higher level of contamination due to proximity to the ground and no muscle support (HENDRICKSON, 2005). Possibly, the lack of muscle support facilitated the Pythium infiltration to structures such as tendons, ligaments and bones, which resulted in a worse prognosis.

\section{Conclusion}

The horses that had total remission of the lesions were the ones submitted to early and aggressive treatment. The success of the treatment depends on the length of the morbidity, the location and size of the lesion. The involvement of deep structures did not allow surgery excision and led to an unfavorable prognosis, with euthanasia being recommended.

\section{References}

AUSTWICK, P. K.; COPLAND, J. W. Swamp cancer. Nature, London, v. 250, n. 461, p. 84, 1974.

BOSCO, S. M. G.; BAGAGLI, E.; ARAUJO, J. P.; CANDEIAS, J. M. G.; FRANCO, M. F. de; MARQUES, M. E. A.; MENDOZA, L.; CAMARGO, R. P.; MARQUES, A. S. Human pythiosis, Brazil. Emerging Infectious Diseases, Atlanta, v. 11, n. 5, p. 715718, 2005.

CALVANO, T. P.; BLATZ, P. J.; VENTO, T. J.; WICKES, B. L.; SUTTON, D. A.; THOMPSON, E. H.; WHITE, C. E.; RENZ, E. M.; HOSPENTHAL, D. R. Pythium aphanidermatum infection following combat trauma. Journal of Clinical Microbiology, Barcelona, v. 49, n. 10, p. 3710-3713, 2011.

CARRERA, M. V.; PEIXOTO, R. M.; GOUVEIA, G. V.; PESSOA, C. R. M.; JESUS, F. P. K.; SANTURIO, J. M.; BOTTON, S. A.; COSTA, M. M. Pitiose em ovinos nos estados de Pernambuco e Bahia. Pesquisa Veterinária Brasileira, Seropédica, v. 33, n. 4, p. 476482, 2013.

CHAFFIN, M. K.; SCHUMACHER, J.; HOOPER, N. Multicentric cutaneous pythiosis in a foal. Journal of American Veterinary Medical Association, Illinois, v. 201, n. 10, p. 310-312, 1992. 
DÓRIA, R. G.; FREITAS, S. H.; LINARDI, R. L.; MENDONCA, F. S.; ARRUDA, L. P.; BOABAID, F. M.; VALADÃO, C. A. Treatment of pythiosis in equine limbs using intravenous regional perfusion of amphotericin B. Veterinary Surgery, Jaboticabal, v. 41 ,n. 6, p. 759-765, 2012.

GAASTRA, W.; LIPMAN, L. J.; DE COCK, A. W.; EXEL, T. K,; PEGGE, R. B.; SCHEURWATER, J.; VILELA, R.; MENDOZA, L. Pythium insidiosum: an overview. Veterinary Microbiology, Barcelona, v. 146, n. 1, p. 1-16, 2010.

GABRIEL, A. L.; KOMMERS, G. D.; TROST, M. E.; BARROS, C. S. L.; PEREIRA, D. B.; SCWEDLER, S. E.; SANTURIO, J. M. Surto de pitiose cutânea em bovinos. Pesquisa Veterinaria Brasileira, Seropédica, v. 28, n. 12, p. 583-587, 2008.

GROOTERS, A. M.; GEE, M. K. Development of a nested polymerase chain reaction assay for the detection and identification of Pythium insidiosum. Journal of Veterinary International Medicine, Louisiania, v. 16, n. 2, p. 147-152, 2002.

HENDRICKSON, D. A. Factors that affect equine wound repair. Veterinary Clinics Equine, Colorado, v. 21, n. 1, p. 33-44, 2005.

KRAJAEJUN, T.; CHONGTRAKOOL, P.; ANGKANANUKUL, K.; BRANDHORST, T. T. Effect of temperature on growth of the pathogenic oomycete Pythium insidiosum. Southeast Asian Journal of Tropical Medicine and Public Health, Wisconsin, v. 41, n. 6, p. 1462-1466, 2010.

LEAL, A. B. M.; LEAL, A. T.; SANTURIO, J. M.; KOMMERS, G. D.; CATTO, J. B. Pitiose equina no pantanal brasileiro: aspectos clínico-patológico de casos típicos e atípicos. Pesquisa Veterinária Brasileira, Seropédica, v. 21, n. 4, p. 151-156, 2001.

MARQUES, S. A.; BAGAGLI, E.; BOSCO, S. M. G.; CAMARGO, R. M. P.; MARQUES, M. E. Pythium insidiosum: relato do primeiro caso de infecção humana no Brasil. Anais Brasileiros de Dermatologia, Rio de Janeiro, v. 81, n. 5, p. 483-485, 2006.

MENDOZA, L.; KAUFMAN, L.; STANDARD, P. G. Immunodiffusion test for diagnosing and monitoring pythiosis in horses. Journal of Clinical Microbiology, Barcelona, v. 23, n. 5, p. 813-816, 1986.
MENDOZA, L.; NICHOLSON, V.; PRESCOTT, J. F. Immunoblot analysis of the humoral immune response to Pythium insidiosum in horses with pythiosis. Journal of Clinical Microbiology, Barcelona, v. 30, n. 11, p. 29802983, 1992.

MOSBAH, E.; KARROUF, G. I.; YOUNIS, E. A.; SAAD, H. S.; AHDY, A.; ZAHOUL, A. E. Diagnosis and surgical management of pythiosis in draft horses: report of 33 cases in Egypt. Journal of Equine Veterinary Science, v. 32, n. 3, p. 164-169, 2012.

SALLIS, E. S. V.; PEREIRA, D. I. B.; RAFFI, M. B. Pitiose cutânea em equinos: 14 casos. Ciência Rural, Santa Maria, v. 33, n. 5, p. 899-903, 2003.

SANTOS, C. E. P.; SANTURIO, J. M.; MARQUES, L. C. Pitiose em animais de produção no Pantanal Matogrossense. Pesquisa Veterinária Brasileira, Seropédica, v. 31, n. 3, p. 1083-1089, 2011 a.

SANTOS, C. E. P.; SANTURIO, J. M.; COLODEL, E. M.; SILVA, J. A.; MARQUES, L. C. Contribuição ao estudo da pitiose cutânea em equídeos do Pantanal Norte, Brasil. ARS Veterinaria, Jaboticabal, v. 27, n. 3, p. 134140, 2011b.

SANTURIO, J. M.; ALVES, S. H.; PEREIRA, D. B.; ARGENTA, J. S. Pitiose: uma micose emergente. Acta Scientiae Veterinariae, Santa Maria, v. 34, n. 1, p. 1-14, $2006 a$.

SANTURIO, J. M.; LEAL, A. T.; LEAL, A. B. M.; ALVES, S. H.; LÜBECK, I. Teste de ELISA indireto para o diagnóstico sorológico de pitiose. Pesquisa Veterinária Brasileira, Seropédica, v. 26, n. 1, p. 47-50, 2006 b.

THEORET, C. L.; WILMINK, J. M. Treatment of exuberant granulation tissue. In: STASHAK, T. S.; THEORET, C. L. Equine wound management. 2. ed. [S.1.]: Willey Blackwell, 2008. p. 445-462.

TORRES NETO, R.; BOSCO, S. M. G. B.; AMORIM, R. L.; BRANDAO, C. V.; FABRIS, V. E.; ESTANISLAU, C.; BAGAGLI, E. Cutaneous pythiosis in a dog from Brazil. Veterinary Dermatology, Botucatu, v. 21, n. 2, p. 202-204, 2010.

WHITE, S. D. Equine bacterial and fungal diseases: a diagnostic and therapeutic update. Clinical Techniques in Equine Practice, Davis, v. 4, n. 4, p. 302-310, 2005. 
